\title{
Three New Recorded Species of the Genus Stenus Latreille (Coleoptera, Staphylinidae, Steninae) in Korea
}

\author{
Kwang-Sik Oh and Young-Bok Cho*
}

Natural History Museum, Hannam University, Ojeong-dong, Daedeok-gu, Daejeon 306-791, Korea

\section{한국산 딱부리반날개속딱정벌리목, 반날개과, 딱부리반날개아과의 미기록 3종 보교}

오광식 · 조영복*

한남대학교 자연사박물관

\begin{abstract}
Three species of the genus Stenus Latreille are reported for the first time in Korea [Stenus (Stenus) latissimus latissimus Bernhauer, $S$. (S.) hammondi Puthz and S. (Hypostenus) dissimilis Sharp]. The adult photographs and the illustrations of aedeagus and 9th sternite of male are provided.
\end{abstract}

Key words: Coleoptera, Staphylinidae, Steninae, Stenus, New records, Korea

초 록: 한국산 딱부리반날개속(Stenus Latreille)의 미기록 3종[Stenus (Stenus) latissimus latissimus Bernhauer, S. (S.) hammondi Puthz 및 S. (Hypostenus) dissimilis Sharp]을 보고한다. 성충사진, 수컷의 생식기 및 9번째 복판 그림을 제시한다.

검색어: 딱정벌레목, 반날개과, 딱부리반날개아과, 딱부리반날개속, 미기록, 한국

\section{Introduction}

The subfamily Steninae is composed of two genera, Dianous Leach and Stenus Latreille (Newton et al., 2001). The genus Stenus is one of the largest of the family Staphylinidae (Tang et al., 2005) and distribution worldwide including more than 2,195 species (Zhao and Zhou, 2004; Puthz, 2005). Most species occur in habitats with high humidity (Rougemont, 1983) and they are characterized by the cylindrical body, elongate maxillary palpi, protruding elongated labium and prementum shape, in addition to extraordinarily convex compound eyes (Naomi, 1990; Zhao and Zhou, 2006).
Haku (1936) described firstly two species in Korea, Stenus (Hypostenus) cicindela $[=S$. (H.) cicindeloides $]$ and S. (S.) tenuipes. After that, 32 species of subfamily Steninae were reported in Korea until now (Yuh et al., 1985; Puthz, 1991).

In this paper, we report three species, Stenus (Stenus) latissimus latissimus Bernhauer, $S$. (S.) hammondi Puthz and $S$. (Hypostenus) dissimilis Sharp, new to Korea. The aedeagus and the 9th sternites of male are illustrated for comparison. The specimens studied are deposited in the Hannam University Natural History Museum (HUNHM), Daejeon, Korea.

*Comesponding author: silpha@hanmail.net

Received February 21 2013; Revised May 102013

Accepted May 282013 


\section{Results}

\section{Stenus (Hypostenus) dissimilis Sharp 작은황다리딱 부리반날개(신칭) (Figs 1A, 2A, 2D)}

Stenus (Hypostenus) dissimilis Sharp, 1874: 87; Puthz, 1968: 44.

Description: Body length: 2.5 3.2 mm, body black, moderately glossy; antenna with the 1 st antenomere dark brown, 2nd to 8th antenomeres dark yellow, 9th to 11th antenomeres dark red; maxillary palpi yellow with the apical palpomere infuscated; legs yellow, the apex of the femora a little darker; labrum black.

Head a little narrower than elytra (0.99:1), clypeofrontal area sparsely pubescent, interocular shallowly concave; basiantennal tubercles small; surface punctures dense, round, distinct and somewhat irregular; interstices between punctures densely reticulated; antenna reaching posterior $3 / 5$ of pronotum, 8 th to 10 th antenomeres ovoidal.

Pronotum shorter than elytra $(0.87: 1)$, a little longer than wide, broadest at anterior $2 / 5$, moderately constricted at base, lateral margins slightly rounded; punctures very dense.

Elytra broader than length (1.04:1), moderately constricted at base, gradually broaden posteriorly, hind margin with a arcuate emargination; surface almost even; punctures round, very dense and large; pubescence short and sparse.

Abdomen broadest at base, weakly narrowed posteriorly; without paratergites except for the trace on basal of 3rd tergite, 4 th to 6 th tergites completely atrophied; punctures dense, round and smaller toward posterior margin, interstices between punctures narrow.

Aedeagus with median lobe strongly bulbous at basal 2/3 and then gradually narrowed toward the pointed apex; parameres slender, extending a little before apex of median lobe, with sparse setae at apico-internal area (Fig. 2A).

Specimens examined. $40^{\circ}, 8 \%$, Chungnam province, Hakampo sand dune, Banggal-ri, Wonbuk-myeon, Taean-gun, 21. VII. 2011, H.K. Min.

Distribution. Korea and Japan.

Remarks. This species can be distinguished from all Korean species of the subgenus Hypostenus by small size (2.5 3.2 mm) and antenna with the 1st antenomere dark brown, 2nd to 8th antenomeres dark yellow, 9th to 11th antenomeres dark red.

\section{Stenus (Stenus) hammondi Puthz 작은날개딱부리반 날개(신칭) (Figs 1B, 2B, 2E)}

Stenus (Nestus) hammondi Puthz, 1970: 31.

Stenus (Stenus) hammondi: Smetana, 2004: 557.

Description: Body length 2.8 3.6 mm, body black, dull; antenna pitchy, maxillary palpi with the 1 st and anterial half of 2nd palpomeres yellow, posterial half of second and 3rd palpomeres brown; legs reddish brown; labrum black.

Head narrower than elytra $(0.95: 1)$, clypeofrontal area sparsely pubescent, interocular area shallowly concave with a pair of depressions, median longitudinal area between the depressions gently convex; basiantennal tubercles small; surface punctures dense, round, distinct and somewhat irregular; antenna reaching posterior $2 / 3$ of pronotum, 8th to 10 th antenomeres ovoidal.

Pronotum a little longer than elytra (1.01:1), a little longer than wide, broadest at anterior $2 / 5$, moderately constricted at base, lateral margins rounded, surface slightly uneven; punctures very dense and coarse.

Elytra broader than length (1.25:1), constricted at base, gradually broadened posteriorly, hind margin with a weak arcuate emargination; surface almost even; punctures subrugose and very dense.

Abdomen broadest at base, narrowed posteriorly, paratergites apparently raised in 3rd to 7th tergites; each of 3rd to 6th tergites with a basimedian keel and a pair of midlateral ones, the keels becoming smaller from 3rd to 6th tergites; punctures dense, round and becoming smaller toward posterior margin, interstices between punctures narrow.

Aedeagus with median lobe a robust, the expulsation-clasp distinctly acute towards the apex; parameres not reaching apex of median lobe, with sparse setae at apico-internal area (Fig 2B).

Specimens examined. $10^{7}$, Gangwon province, Mt. Odaesan, Pyeongchang-gun, 20. IV . 2002, C.W. Sin; $10^{\star}, 1$ \& , Gangwon province, Mt. Jeombongsan, Jindong-ri, Girin-myeon, Injae-gun, 18. IV. 2007, S.M. Yoon; 1 우, Gangwon province, Mt. Odaesan, 
Sangwonsa Temple, Dongsan-ri, Jinbu-myeon, Pyeongchang-gun, 19. IV. 2007, H.K. Min; $20^{x}, 3$ 우, Gangwon province, Mt. Odaesan, Jinbu-myeon, Pyeongchang-gun, 22. V . 2012, D.H. Lee, Y.G. Ban, S.G. Lee.

Distribution. Korea, China, Japan and Russia (Far East).

Remarks. This species is silmilar to $S$. lewisius and $S$. distans by each of 3rd to 6th tergites with a basimedian keel and a pair of midlateral keels but can be distinguished from $S$. lewisius by elytra broader than length, and also differs from $S$. distans by reddish brown legs.

\section{Stenus (Stenus) latissimus latissimus Bernhauer 큰딱지딱부리반날개(신칭) (Figs. 1C, 2C, 2F)}

Stenus (Nestus) latissimus Bernhauer, 1938: 29.

Stenus (Nestus) gibbicollis canus Puthz, 1966: 303; Puthz, 1967: 78 .

Stenus (Stenus) latissimus latissimus: Smetana, 2004: 558.

Description: Body length 3.0 4.3 mm, body black and dull; antenna dark brown, with apical antenomere reddish brown; maxillary palpi with the 1st palpomere yellow, 2nd and 3rd palpomeres dark brown; legs and labrum black.

Head narrower than elytra $(0.80: 1)$, clypeofrontal area sparsely pubescent, interocular area shallowly concave with a pair of depressions, median longitudinal area between the depressions gently convex, basiantennal tubercles small, surface punctures dense, round, and distinct; antenna reaching posterior $2 / 3$ of pronotum, 9 th and 10th antenomeres ovoidal.

Pronotum shorter than elytra $(0.62: 1)$, a little broader than length, broadest at anterior $2 / 5$, moderately constricted at base, lateral margins rounded, surface slightly even; punctures dense.

Elytra a little broader than length (1.01:1), constricted at base, gradually broaden posteriorly, hind margin with a arcuate emargination, surface almost even; punctures round, very dense and large.

Abdomen broadest at base, narrowed posteriorly, paratergites apparently raised in 3rd to 7th tergites; punctures dense, round and becoming smaller toward posterior margin, interstices between punctures narrow.
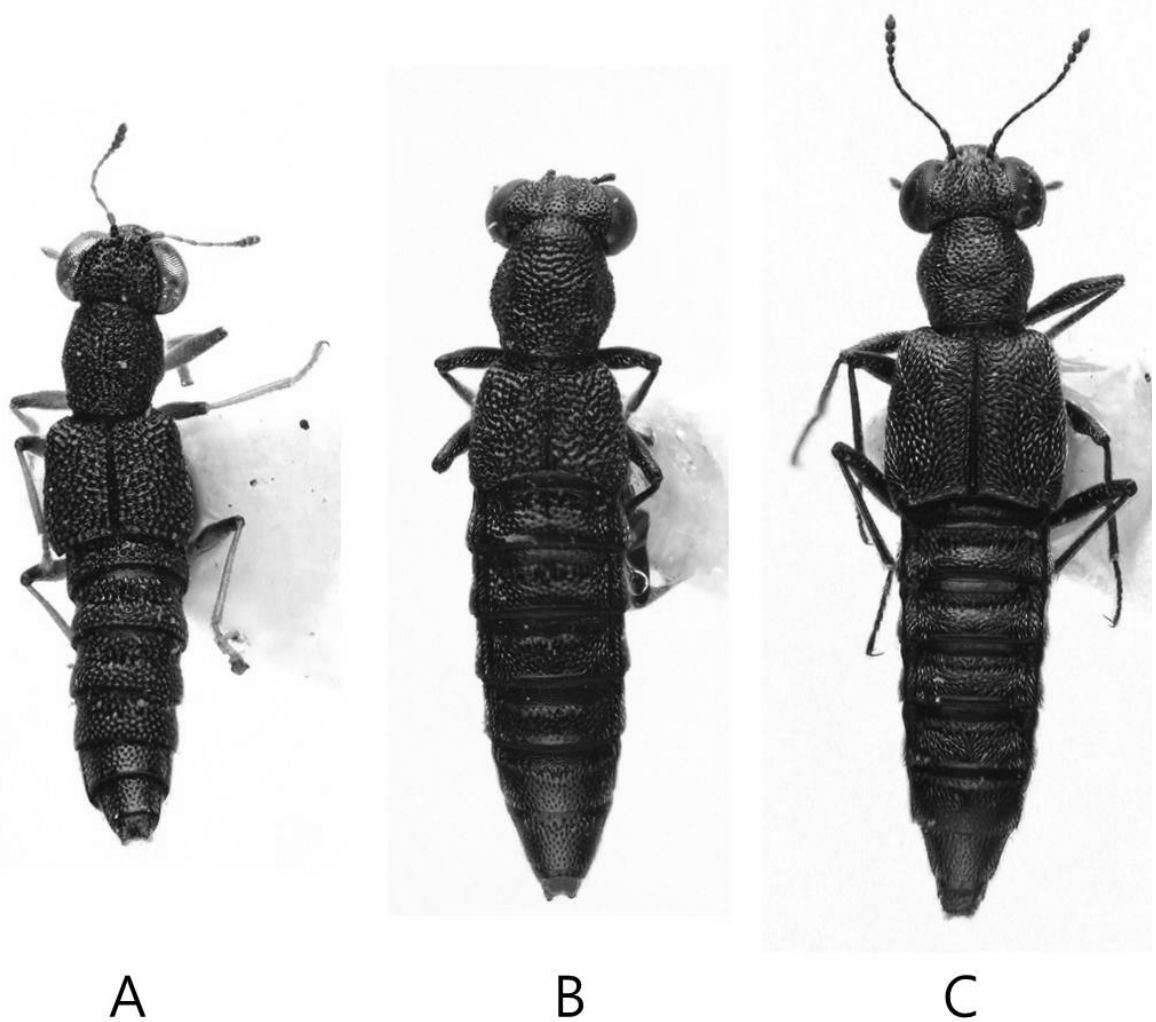

B

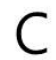

Fig. 1. Habitus. A, S. (H.) dissimilis (2.9 mm); B, S. (S.) hammondi (3.6 mm); C, S. (S.) latissimus latissimus (4.3 mm). 

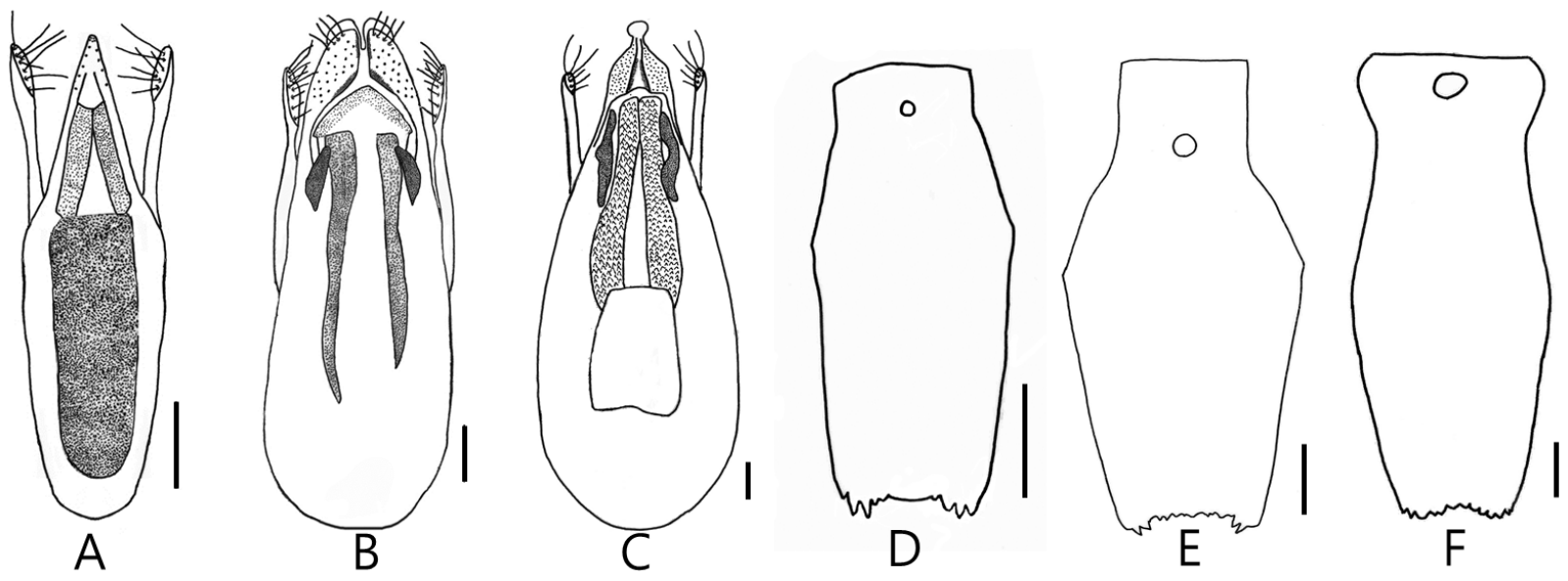

Fig. 2. Aedeagus $(\mathrm{A} \sim \mathrm{C})$ and 9th sternite (D F) of male in ventral view. $\mathrm{A}$ and $\mathrm{D}, \mathrm{S}$. (H.) dissimilis; $\mathrm{B}$ and $\mathrm{E}, \mathrm{S}$. (S.) hammondi; $\mathrm{C}$ and $\mathrm{F}, \mathrm{S}$. (S.) latissimus latissimus. Scale bars $=0.1 \mathrm{~mm}$.

Aedeagus with median lobe elongate, broadest at about basal $1 / 3$, then gradually narrowed toward apex, the apex round like nipple, parameres slender, not reaching apex of median lobe, with sparse setae at apico-internal area (Fig. 2C).

Specimens examined. $10^{7}, 1 \%$, Gangwon province, Mt. Seoraksan, Baekdam valley, Buk-myeon, 10. VI. 2011, J.H. Song, S.G. Lee.

Distribution. Korea, China, Mongolia and Russia (East Siberia, Far East).

Remark. There are two subspecies (S. latissimus latissimus and S. latissimus hatchi) within Stenus latissimus (Herman, 2001). The latter subspecies is distributied in USA and Canada (Herman, 2001). S. latissimus latissimus can be distinguished from Korean species of subgenus Stenus by the apex of median lobe with nipple shape.

\section{Acknowledgement}

This research was supported by the project on the survey and excavation of Korean indigenous Species of the National Institute of Biological Resources (NIBR) of Ministry of Environment, Korea.

\section{Literature Cited}

Bernhauer, M., 1938. Zur Staphylinidenfauna von China u. Japan. (9. Beitrag). Ent. Nachrbl. 12, 17-39.
Haku, K., 1936. A list of insects collected from North Keisho-Do, Korea. Journal of Chos. Nat. Hist. Soc. 21, 115-125.

Herman, L.H., 2001. Catalog of the Staphylinidae (Insecta: Coleoptera). 1758 to the end of the second millennium (Parts IV). Bull. Am. Mus. Nat. Hist., 265, 2007-2439.

Naomi, S.I., 1990. Studies on the subfamily Steninae (Coleoptera, Staphylinidae) from Japan, XVII. Descriptions of Five New Species of the Genus Stenus Latreille. Nat. Hist. Res. 1, 99-107.

Newton, A.F., Thayer, M.K., Ashe, J.S., Chandler, D.S., 2001. 22. Staphylinidae Latreille, 1802. In: Arnett RH, Thomas MC (eds.) American beetles: Archostemata, Myxophaga, Adephaga, Polyphaga: Staphyliniformia, vol 1. CRC Press, Boca Raton, FL, pp. 272-418.

Puthz, V., 1966. über nord-und ostpaläarktische Steninen (Coleoptera, Staphylinidae). 25. Beitrag zur Kenntnis der Steninen. Ann. Entomol. Fenn. 32, 295-308.

Puthz, V., 1967. 75. Staphylinidae: Steninae Ergebnisse der zoologischen Froschungen von Dr. Z. Kaszab in der Mongolei (Coleoptera). 17. Beitrag zur Kenntnis der Steninen mit 6 Figuren. Reichenbavhia Mus. Tierk. Dresden 9, 75-83.

Puthz, V., 1968. On Some East Palearctic Steni, Particularly from Japan (Coleoptera, Staphylinidae) 52. Contribution to the Knowledge of Steninae. Entomol. Rev. Japan. 20, 41-51.

Puthz, V., 1970. On a collection of Steninae from China (Coleoptera: Staphylinidae). Proc. R. Entomol. Soc. Lond. 39, 29-32.

Puthz, V., 1991. Wietere Stenus-Arten aus Korea, nebst synonymischen bemerkungen (Coleoptera, Staphylinidae). Ann. Hist.-Nat. Mus. Nat. Hung. 83, 103-110.

Puthz, V., 2005. Ein Dutzend neuer palaarktischer Stenus-Arten (Coleoptera, Staphylinidae) 290. Beitrag zur Kenntnis der Steninen. Entomol. B1. 101, 171-196.

Rougemont, G.M. de, 1983. More Stenine beetles from Thailand 
(Coleoptera, Staphylinidae). Nat. Hist. Bull. Siam Soc. 31, 9-54.

Sharp, D.S., 1874. Staphylinidae of Japan. Trans. Ent. Soc. Lond. 1874, 1-103.

Smetana, A., 2004. Family Saphylinidae: Omaliinae, Proteininae, Micropeplinae, Dasycerinae, Phleocharinae, Olisthaerinae, Tachyporinae, Trichophyinae, Habrocerinae, Aleocharinae, Trigonurinae, Apaticinae, Piestinae, Osoriinae, Oxytelinae, Oxyporinae, Megalopsiinae, Steninae, Euaesthetinae, Leptotyphlinae, Pseudopsinae, Paederinae, Staphyliniae. In: Löbl, I. \& Smetana, A. (Eds), Catalogue of Palaearctic Coleoptera. Volume2. Apollo Books, Stenstrup. pp. 540-564.
Tang, L., Li, L.Z., Zhao, M.J., 2005. Three New Species of the Group of Stenus cirrus (Coleoptera, Staphylinidae) from China. Elytra, Tokyo, 33, 609-616.

Yuh, J.H., Paik, W.H., Kwon, Y.J., Lee, S.M., 1985. Check list of rove beetles from Korea. Ins. Kor. 5, 224-255.

Zhao, C.Y., Zhou H.Z., 2004. Five new species of genus Stenus Latreille (Coleoptera: Staphylinidae) from China. Pan-pac. Entomol. 80, 93-101.

Zhao, C.Y., Zhou, H.Z., 2006. Three new species of the genus Stenus Latreille (subgenus Stenus s. str.) from China (Coleoptera, Staphylinidae, Steninae). Mitt. Mus. Nat.kd. Berl., Dtsch. Entomol. 53, 282-289. 